\title{
New insights into the materials of fifteenth- and sixteenth-century Netherlandish paintings in the National Gallery, London
}

\author{
Marika Spring ${ }^{*}$
}

\begin{abstract}
The long-term programme of technical examination conducted at the National Gallery, London, during cataloguing of the Netherlandish School paintings surveyed the materials and techniques of a wide range of artists, including not only Van Eyck, Van der Weyden, Bosch, Bruegel, Massys and Gossaert but also lesser known painters from the same period. The research presented in this article brings together both published and unpublished results from this project, strengthening the trends that had been emerging and bringing new insights into the development of artists' materials over this period. A notable finding during the programme was the discovery of two paint additives-colourless powdered glass and zinc sulphate (white vitriol) - probably added as driers. The new quantitative analyses of the glass composition presented here add to those already published, and reveal that towards the end of the fifteenth century high lime-low alkali glass begins to be used. This observation holds the potential to contribute to questions about the dating of Netherlandish paintings. A smaller number of occurrences of zinc sulphate were identified suggesting that it was less common than glass as an additive, but it is nevertheless significant since it was used by a key figure in the history of oil painting, Jan van Eyck, and occasionally, where present in excess, has caused conservation problems such as drying defects in the paint. Occurrences of the unusual pigments vivianite and fluorite were identified in a few sixteenth-century works. The main changes encountered during the period, however, were the introduction of the blue pigment smalt, its instability having consequences for the current appearance of the paintings, and of a green copper mineral pigment composed of mainly copper sulphate. The latter has proved to be far more common than had been realised in the past.
\end{abstract}

Keywords: Netherlandish painting, Pigments, Fifteenth century, Sixteenth century, Driers, Colourless powdered glass, Zinc sulphate, Smalt, Vivianite, Purple fluorite, Green mineral copper sulphate

\section{Introduction}

Since the pioneering research on Van Eyck's Ghent Altarpiece in the 1950s [1], there have been many technical studies of Early Netherlandish paintings, providing a considerable body of knowledge on their materials and techniques. These have often focussed, however, on the most prominent artists, or on individual paintings. The National Gallery's long-term cataloguing programme was an opportunity to survey a wider range of artists,

*Correspondence: marika.spring@ng-london.org.uk National Gallery, Trafalgar Square, London WC2N 5DN, UK including not only Jan van Eyck, Rogier van der Weyden, Hieronymus Bosch, Pieter Bruegel the Elder and Jan Gossaert but also lesser known painters from the same period. The results from the first stage of the programme, concentrating on the earlier paintings, were published in the 1997 volume of the National Gallery Technical Bulletin [2], a special issue on Early Northern European painting, and in the 1998 fifteenth-century school catalogue [3]. These findings were updated during more recent research on works by Rogier van der Weyden [4] and Jan van Eyck [5] that probed the materials in more detail. This took advantage of the more sophisticated analytical 
techniques now available, as did the examinations for the sixteenth-century Netherlandish and French school catalogue published in 2014 [6].

The cataloguing programme included technical examination of all the fifteenth- and sixteenth-century Netherlandish and French paintings in the National Gallery, around 120 in total. Certain works were studied in more depth than others, but for almost all of them at least a few samples were taken to investigate paint composition and layer structure. It was not possible, or appropriate, to describe the analyses in detail in these scholarly art-historical catalogues. The purpose of this article is therefore to present a selection of the scientific results behind the brief summaries included in the technical notes of each entry in the published catalogues, concentrating here on a few topics of particular interest. Some of the findings have already been published in articles focussed on certain materials $[7,8]$, but here they are augmented with further new results and are brought together to consider their use in the specific context of Netherlandish paintings. This overview also provides insight into the technical changes that accompany the changes in style evident when moving from the fifteenth to the sixteenth century.

The pigments found in the fifteenth-century paintings were familiar-verdigris for greens, azurite and ultramarine for the blues, vermilion, red lead and red lakes for the reds and so on. Of most interest were two materials that functioned not as pigments but as additives to modify the properties of the paint; colourless powdered glass, and zinc sulphate, also known as zinc vitriol or white vitriol. These were also seen in the sixteenth-century works, but there were differences among the pigments when compared to the earlier paintings, such as the occasional use of the rare pigments fluorite and vivianite, and more significantly the introduction of the blue pigment smalt and a green mineral pigment composed predominantly of a copper sulphate.

\section{Paint additives}

\section{Colourless powdered glass}

Colourless powdered glass has so far proved to be the more common of the two additives discussed here. It was first reported in 2003 in paintings by the Italian artists Raphael and Perugino $[9,10]$, identified by the conchoidal fracture lines and jagged shape of particles seen in paint cross-sections, as well as the characteristic series of elements detected by SEM-EDX analysis. It quickly became apparent, however, that it was present in fifteenth- and sixteenth-century paintings from all over Europe $[9,11$, 12]. In the subsequent broader study of this additive in 70 paintings in the National Gallery, published in 2012, forty of the examples were in Italian paintings [8]. Although this apparent geographical bias may reflect to some extent the greater number of samples from Italian paintings that have been analysed with this material in mind, it is consistent with the comment made by the English painter Marshall Smith in 1693 that it was 'much used in Italy' [13]. Among the 29 Northern European occurrences discovered in National Gallery paintings during the 2012 study are 15 in Netherlandish works, 12 from Germany and 2 from France [8]. Five more were found subsequently during cataloguing of the sixteenth-century Netherlandish paintings, to which can be added the examples that have been reported in paintings from other collections $[14,15]$. The earliest known occurrence so far is in a German work, Lucas Moser's Tiefenbronn Altarpiece of 1432 [15], while the earliest among the National Gallery paintings was in a Netherlandish work, The Arnolfini Portrait by Jan van Eyck, painted only 2 years later in 1434 (Fig. 1) [8]. Van Eyck added it to his purple and red glazes in this portrait, as he did again in The Annunciation (1434-36, National Gallery of Art, Washington DC), where it is also a component of the mordant for the gilding. His use of a material that was not a pigment but that would have influenced the properties of the paint is especially interesting given the pivotal role he is thought to have played in the development of oil painting technique [5].

Colourless powdered glass is mentioned in numerous historic documentary sources, in recipes for boiled oils, as an additive mixed with the paint on the palette, as an ingredient in a mordant for gilding, and occasionally to aid in the grinding of orpiment. The texts often suggest that it was a siccative for oil, and whatever the outcome of the further experiments needed to provide decisive proof that it is effective for this purpose, the belief that it could perform this function may have been the main reason that artists used it (at least in paintings, rather than the other contexts in which this material is sometimes mentioned). This does not preclude the possibility that they appreciated, in addition, any effect it had on the optical or handling properties of the paint $[8,14,15]$. The review of the documentary sources published in 2012 in the National Gallery Technical Bulletin [8] includes references to this material in a few fifteenth- and early sixteenth-century treatises, but the earliest that states explicitly that it was added as a siccative-in this case for orpiment bound in oil-is Richard Haydocke's 1598 translation of Lomazzo, in a marginal note by Haydocke that does not appear in the original Italian treatise. It is most often recommended as an addition to improve the drying of oil paint containing red lakes or blacks. The published occurrences indeed indicate that it was most commonly mixed with these pigments, although certain artists such as Raphael [8] and Holbein the Elder [15] seem to have used it rather more extensively in other 

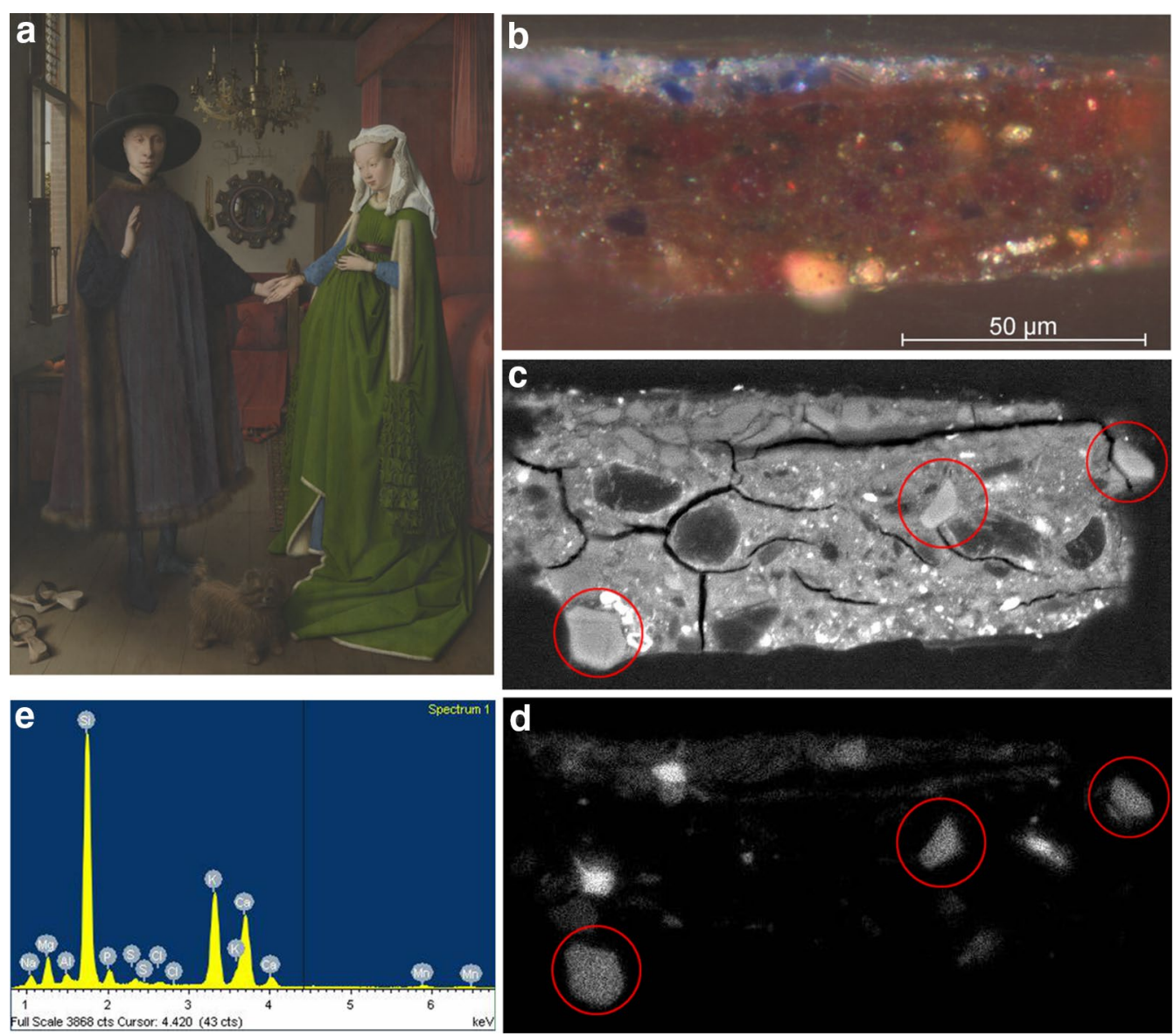

Fig. 1 a Jan van Eyck, The Arnolfini Portrait (NG186), 1434, oil on oak, $82.2 \times 60 \mathrm{~cm}$; b paint cross-section from the man's plum-coloured robe, showing a thick layer of red lake, ultramarine and colourless powdered glass, on top of which is a thin ultramarine layer which appears light because it is degraded and blanched; $\mathbf{c}$ backscattered electron SEM image of the cross-section, with the glass particles circled in red; $\mathbf{d}$ silicon EDX map of the cross-section with the glass particles circled in red (the other silicon-containing particles are ultramarine); e EDX spectrum of one of the glass particles showing the characteristic series of elements. Images @ National Gallery, London

colours. Three of the five new occurrences published here (Table 1) are in paint containing red lake or black, although in one it is combined with vermilion (another poor drying pigment) and in another it is in a green mixture which, although it includes some black pigment, is composed predominantly of lead white and lead-tin yellow. In this last example powdered glass may have been added because the green is an underpaint, where rapid drying would allow the upper layers to be applied without much delay; this is perhaps similar to the numerous paintings where it was used in primings, even though they contain lead white which itself aids drying of the oil [8].

The anonymous late sixteenth-century French manuscript from Toulouse BnF Ms. Fr. 640 (Bibliothèque Nationale, Paris), not included in the earlier review [8], mentions colourless ground glass several times. It is being transcribed and translated for an online critical edition during 'The Making and Knowing Project' directed by Pamela H. Smith at Columbia University, New York [16]. This historical source, in the form of a 'book of secrets', is especially helpful in furthering understanding of the motivation behind the use of this additive, since it gives a more explicit explanation as to why it might have been used, and what properties it was considered to confer to the oil paint.

On the verso of page 56 it states that 'Lake takes a long time to dry in oil, and for that reason you have to grind some glass with it. But you have to choose crystallin, because it is cleaner. Crystallin at this time would have meant clear colourless glass containing manganese as a decolorizer to counteract the greenish tint caused by the iron naturally present in the silica source used for ordinary glass. This seems invariably to have been the type of 


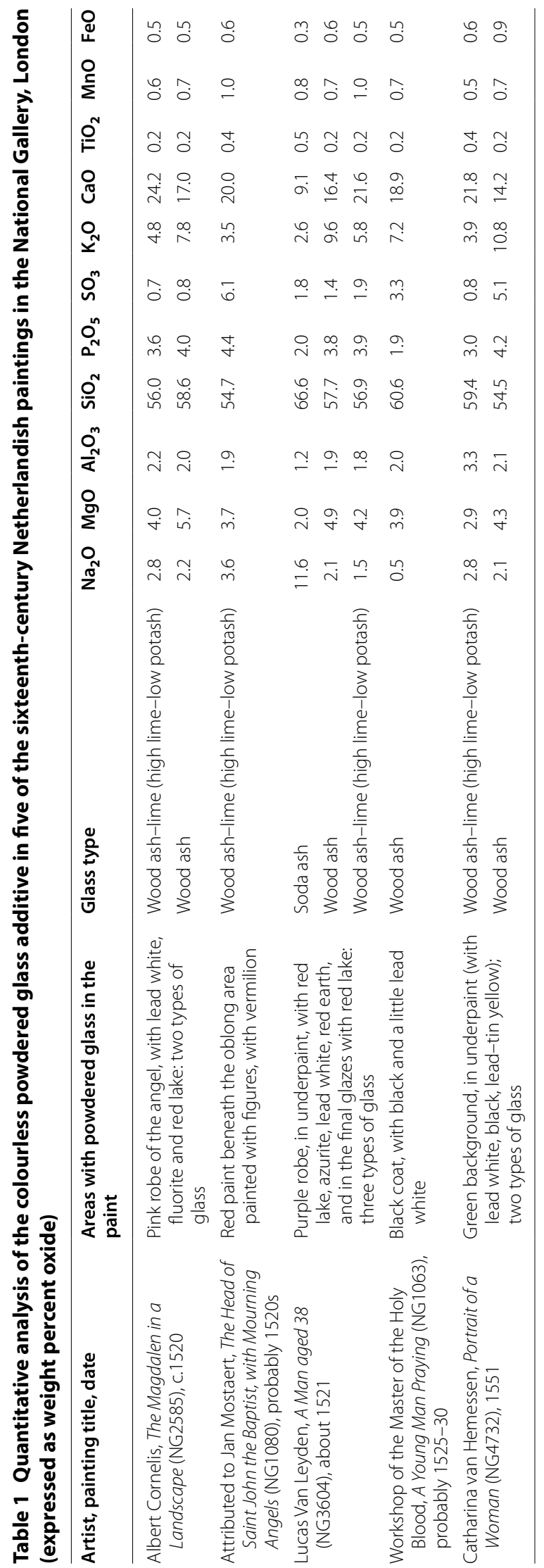


glass used as an additive in paintings, since the quantitative analyses show that in every case some manganese is present [8]. It is well known that manganese can act as a siccative for oil, although it is not yet clear whether this element is sufficiently mobile in the glass to perform this function, and it may be that the alkali content proves to be more important in this respect [8]. In northern European glass manganese is likely to have been introduced as part of the wood ash used as the flux, rather than as a separate component [17].

The passage on page 56 in this manuscript goes on to say 'And because it would be too difficult to grind it as it is, it must be made red hot in the fire, then once completely red throw it into cold water and it will crumble and become powdery and then be ground easily. After being well ground in a lot of water, it looks like ground lead white, but, despite this, it does not in fact have body'. The verso of page 57 expands on this last phrase, stating that 'Crystallin having been ground in water appears to have body, but in oil it does not have any. It is ground with lake and with aspalthe, which will not dry for a very long time without it.' As in other treatises, the ground glass is to be mixed with red lake and a black pigment as a siccative.

On the verso of page 65 it is suggested that glass could also be added for another purpose. In a passage on glazing, it states that 'One usually glazes with colours that do not have any body, such as lake and verdigris. However, in order to use other colours, [in other words, more opaque pigments] one mixes them with a quantity of calcined and ground crystallin, which also does not have any body, reducing their density.' A note in the margin of page 65 recto clarifies what is meant, stating that 'Every colour or thing which appears dense when mixed with water, on being ground, has body. But those which do not have it [body], such as crushed glass and lake etc., are made clear.' It is evident that here materials without body are translucent, and that in this case the powdered glass is certainly being used to alter the optical properties of the paint. This passage, however, concerns paints for decorating cast metal objects where glazes that allowed the metal surface to shine through were required. It is made clear that it is not needed to increase translucency when using inherently translucent pigments such as red lakes. This source makes it evident that crushed colourless glass could have several purposes, but the manner in which it has been used in paintings suggests that there it was intended as a siccative. It was mixed not only with red lakes and blacks-both poorly drying pigments-but also used in mordants for gilding where it would have no optical function since it was hidden beneath gold leaf, and in primings where again it would be covered by paint [8].
In addition to revealing the presence of manganese, the quantitative SEM-EDX analyses indicate the type of glass in each case. This is dependent on the raw materials used to make it, including the silica source, whether pebbles or sand, and especially the type of ash that was the source of the alkali flux. In the Mediterranean area the ash of coastal halophytic plants was used, producing soda-ash glass rich in sodium, as found in all except one of the Italian paintings analysed at the National Gallery. Glass of this type was also identified in the National Gallery's Northern European paintings, including five of the twelve German works (see table in [8]). Several more examples in German works were published by Lutzenberger, who also found it in one Netherlandish work by Colijn de Coter painted before 1510 [14]. Another Netherlandish occurrence is added here; Lucas Van Leyden's, A Man aged 38 (NG3604) of about 1521 (Table 1). In the fifteenth century and the early sixteenth century this glass is likely to have been imported from Italy, although a little later soda-ash glass was being made in the Netherlands following the arrival of Italian glassmakers in centres such as Antwerp [18].

In Netherlandish paintings calco-potassic glass made with potassium-rich wood ash or fern ash was more common. The main constituents, in addition to silica, are varying amounts of potassium and calcium, with lesser but still significant amounts of magnesium. From the thousands of analyses of vessel and window glass several compositional categories have been identified based on the proportions of $\mathrm{K}_{2} \mathrm{O}$ and $\mathrm{CaO}$ (see references and summary in [8]). The calcium originates either from the inclusion of lime in the recipe or from the ash, depending on the type of wood, the growing conditions or the proportion of trunk to twigs (the bark being richer in calcium). Glasses with potassium and calcium contents (as weight percentage oxide) ranging from roughly equal up to one and a half or two times as much calcium as potassium are generally designated as wood ash glasses. An example of glass in this category is the second type identified in Catharina van Hemessen's Portrait of a Woman (NG 4732) (Table 1). Where more calcium is present, above $20 \% \mathrm{CaO}$, together with relatively high levels of $\mathrm{K}_{2} \mathrm{O}$ of $6-9 \%$ it can be categorised as wood ash-lime. All of the wood ash-lime glass in Table 1 is of another type within this category, generally called high lime-low alkali, with a much lower level of $\mathrm{K}_{2} \mathrm{O}$ at only $3.5-5 \%$ and high levels of calcium at $20-25 \%$.

Looking at the type of glass when the Netherlandish paintings are listed in chronological order (Table 2) an interesting trend emerges. Quantitative results have been obtained from 19 of the 23 paintings containing powdered glass. Of these, ten are high lime-low alkali glass, 
Table 2 Type of colourless powdered glass additive in fifteenth- and sixteenth-century Netherlandish paintings in the National Gallery, London, in chronological order

\begin{tabular}{|c|c|c|c|}
\hline Artist & Painting (medium and support) & Date & Type(s) of glass \\
\hline Jan van Eyck & $\begin{array}{l}\text { Portrait of Giovanni(?) Arnolfini and his Wife } \\
\text { (NG186), oil on oak }\end{array}$ & 1434 & $\begin{array}{l}\text { Three types: wood ash with some fern ash, } \\
\text { wood ash, wood ash-lime }\end{array}$ \\
\hline Rogier van der Weyden & $\begin{array}{l}\text { The Magdalen Reading (NG654), oil on } \\
\text { mahogany, transferred from another } \\
\text { panel }\end{array}$ & Before 1438 & Wood ash \\
\hline Follower of Robert Campin & $\begin{array}{l}\text { The Virgin and Child before a Firescreen } \\
\text { (NG2609), oil on oak with walnut addi- } \\
\text { tions }\end{array}$ & About 1440 & Wood ash \\
\hline $\begin{array}{l}\text { Probably by the workshop of Rogier van } \\
\text { der Weyden }\end{array}$ & Pietà (NG6265), oil on oak & About 1465 & Wood ash \\
\hline Dirk Bouts & The Virgin and Child (NG2595), oil on oak & About 1465 & Wood ash-lime \\
\hline Workshop of Dirk Bouts & The Virgin and Child (NG708), oil on oak & About 1465 & Wood ash \\
\hline Dirk Bouts & $\begin{array}{l}\text { Christ Crowned with Thorns (NG1083), oil } \\
\text { on canvas backed onto board, trans- } \\
\text { ferred from wood }\end{array}$ & About 1470 & Wood ash-lime (high lime/low alkali) \\
\hline Hieronymus Bosch & $\begin{array}{l}\text { Christ Mocked (The Crowning with Thorns) } \\
\text { (NG4744), oil on oak }\end{array}$ & About 1510 & Wood ash-lime (high lime/low alkali) \\
\hline After Robert Campin & $\begin{array}{l}\text { The Virgin and Child in an Apse with Two } \\
\text { Angels (NG2608), oil on oak }\end{array}$ & About $1500 ?$ & Wood ash-lime (high lime/low alkali) \\
\hline Workshop of Goossen van der Weyden & The Flight into Egypt (NG1084), oil on oak & About 1516 & Wood ash-lime (high lime/low alkali) \\
\hline Albert Cornelis & $\begin{array}{l}\text { The Magdalen in a Landscape (NG2585), } \\
\text { oil on oak }\end{array}$ & About 1520 & $\begin{array}{l}\text { Two types: wood ash and wood ash-lime } \\
\text { (high lime/low alkali) }\end{array}$ \\
\hline Probably by Jan Mostaert & $\begin{array}{l}\text { The Head of Saint John the Baptist, with } \\
\text { Mourning Angels (NG1080), oil on oak }\end{array}$ & Probably 1520 s & Wood ash-lime (high lime/low alkali) \\
\hline Workshop of Jean Bellegambe & The Virgin and Child (NG265), oil on oak & About 1520 & Wood ash-lime (high lime/low alkali) \\
\hline Lucas van Leyden & A Man aged 38 (NG3604), oil on oak & About 1521 & $\begin{array}{l}\text { Three types: soda ash, wood ash and wood } \\
\text { ash-lime (high lime/low alkali) }\end{array}$ \\
\hline Workshop of the Master of the Holy Blood & A Young Man Praying (NG1063), oil on oak & Probably $1525-30$ & Wood ash \\
\hline Martin van Heemskerck & $\begin{array}{l}\text { The Virgin and Saint John the Evangelist } \\
\text { (NG 6508.1), }\end{array}$ & About 1540 & Wood ash \\
\hline Workshop of Marinus van Reymerswaele & Two Tax-Gatherers (NG944), oil on oak & Probably 1540 s & Wood ash-lime (high lime/low alkali) \\
\hline Catharina van Hemessen & Portrait of a Woman (NG4732), oil on oak & 1551 & $\begin{array}{l}\text { Two types: wood ash and wood ash-lime } \\
\text { (high lime/low alkali) }\end{array}$ \\
\hline Joachim Beuckelaer & $\begin{array}{l}\text { The Four Elements: Air (NG6587), oil on } \\
\text { canvas }\end{array}$ & 1570 & Wood ash-lime \\
\hline
\end{tabular}

but they all date from after 1470 . This mirrors the patterns identified from the extensive past analyses done on vessel glass, which have shown that this type of glass starts to become common only from the end of the fifteenth century onwards in the Netherlands [19]. Only one of the examples dates from before 1500-Christ crowned with Thorns (NG1083) by Dirk Bouts, which is thought to have been painted around 1470. It is worth noting that this painting has been in the past attributed to Albrecht Bouts rather than his father Dirk and given a date of around 1500 [20], although it is only with a greater number of results that it will be possible to say with more certainty whether this type of glass has a bearing on the date or whether it was already being used in paintings by the 1470s. This trend in the composition of glass in paintings, presented already as a tentative hypothesis in 2012 [8], is strengthened considerably by the results added here from sixteenth-century paintings (Table 1), which include four occurrences of high lime-low alkali glass. The composition of the glass may prove to be useful in dating of a work, and could be especially helpful for distinguishing later variants from earlier works produced by certain studios such as the Bouts workshop, where later generations of artists continued to use the same models or patterns for their compositions transmitted through drawings.

\section{Zinc vitriol (white vitriol, white copperas, zinc sulphate)}

During re-analysis of samples from Jan van Eyck's Arnolfini Portrait (NG186) in 2012 a small but significant amount of zinc was detected in the purple paint mixture of red lake and ultramarine on the man's robe. This was most probably incorporated in the form of zinc sulphate 
(zinc vitriol, white vitriol, white copperas), which, like powdered glass is recommended as a siccative for oil in various historical documentary sources, or as an ingredient in the preparation of boiled oils [5]. It is also an ingredient in a red lake recipe in the German fifteenth-century Tegernsee manuscript [21], making it possible that it is associated with the pigment, but in another work by Jan van Eyck, the portrait of his wife, Margaret (Groeningemuseum, Bruges), it is not only present in the red lake glazes on her dress but also in the black background [5]. This suggests it is more likely to have been added to the paint rather than being part of the red lake. The same is true in another example, a portrait by the sixteenth-century French artist François Quesnel, where it was located in the pinkish priming, together with lead white and a little red lead (Fig. 2).

A zinc-rich yellow earth pigment has been found in Venetian sixteenth-century paintings [22], however, and it is therefore important to establish that the zinc really is present as zinc sulphate, and hence has been added as zinc vitriol. In Titian's Portrait of a Man (NG1944), the SEM-EDX analyses indicated clearly that zinc and sulphur are located together in the same zones in the priming. ATR-FTIR microspectroscopic imaging on a cross-section confirmed they are present in the form of zinc sulphate, the spectra showing a characteristic infrared absorption band at around $1070 \mathrm{~cm}^{-1}$. Infrared absorption bands at 1530, 1454 and $1397 \mathrm{~cm}^{-1}$ further indicated that the zinc has reacted with the oil binder to form zinc soaps, which are evident as large translucent inclusions [23].

Since few occurrences of zinc vitriol as an additive have been confirmed, all those identified so far in National Gallery paintings, from all over Europe, are listed in Table 3. Most of these identifications rely only on SEMEDX analysis, but ATR-FTIR imaging was carried out wherever possible to confirm that zinc was indeed present as zinc sulphate (although not all the cross-sections were suitable for this type of analysis). The list includes, in addition to the works by Van Eyck and François Quesnel,
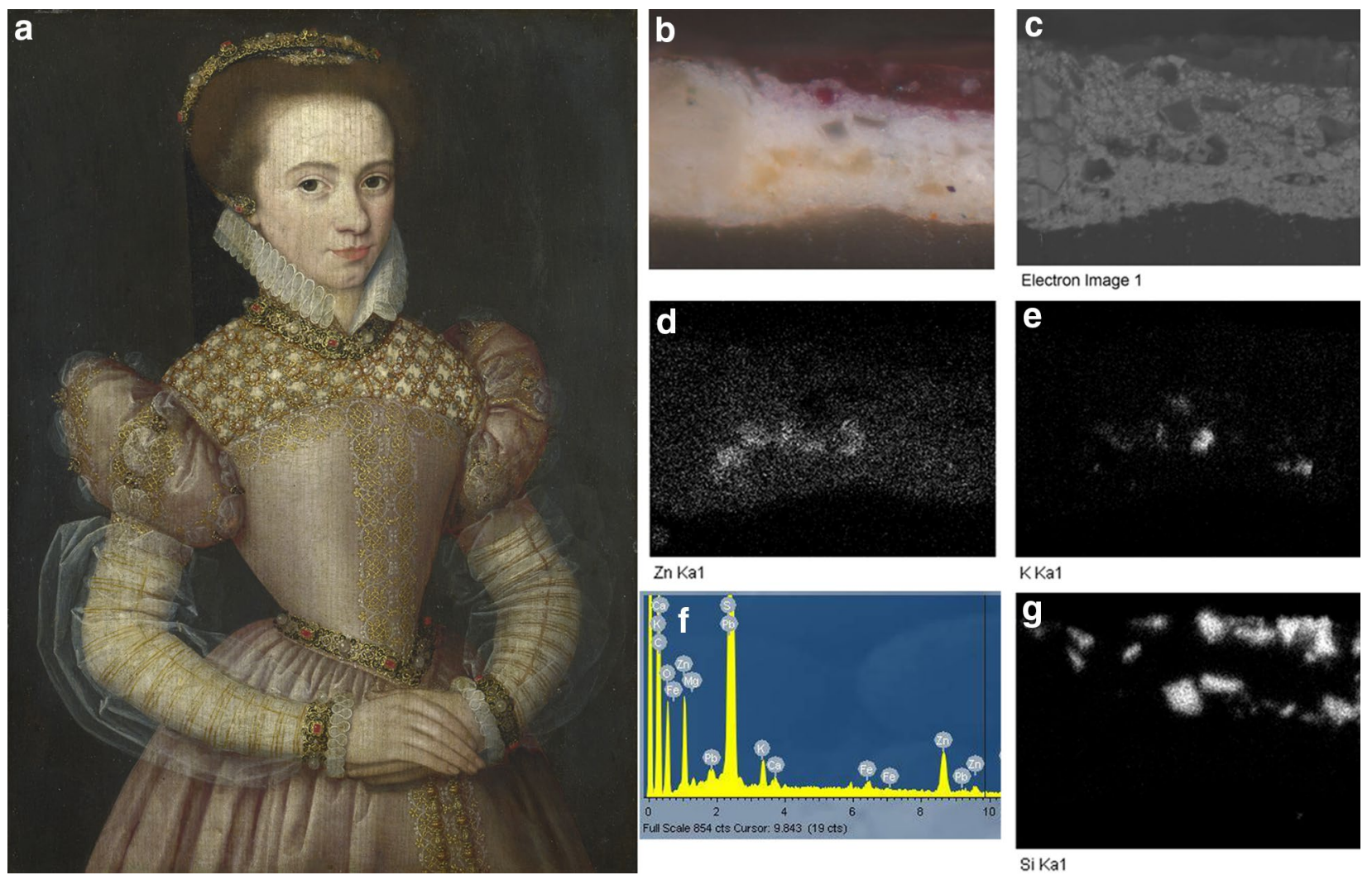

KKa1

Fig. 2 a François Quesnel, Portrait of a Lady (NG2617), about 1575, oil on oak, $36.9 \times 27.6 \mathrm{~cm}$; b paint cross-section from the purple-pink dress, showing the light orange priming consisting of lead white, a little red lead and a little zinc sulphate, on top of which is a light blue layer of smalt and lead white, followed by a pink layer of lead white, red lake and smalt, followed by a final deeper layer of red lake and smalt; c backscattered electron SEM image of the cross-section; $\mathbf{d}$ zinc EDX map showing the zinc sulphate in the priming, e potassium EDX map showing the areas where potassium is associated with zinc; $\mathbf{f}$ EDX spectrum from a zinc- and potassium-rich area showing that potassium is associated with the zinc; $\mathbf{g}$ silicon EDX map showing the location of the smalt particles. Images @ National Gallery, London 


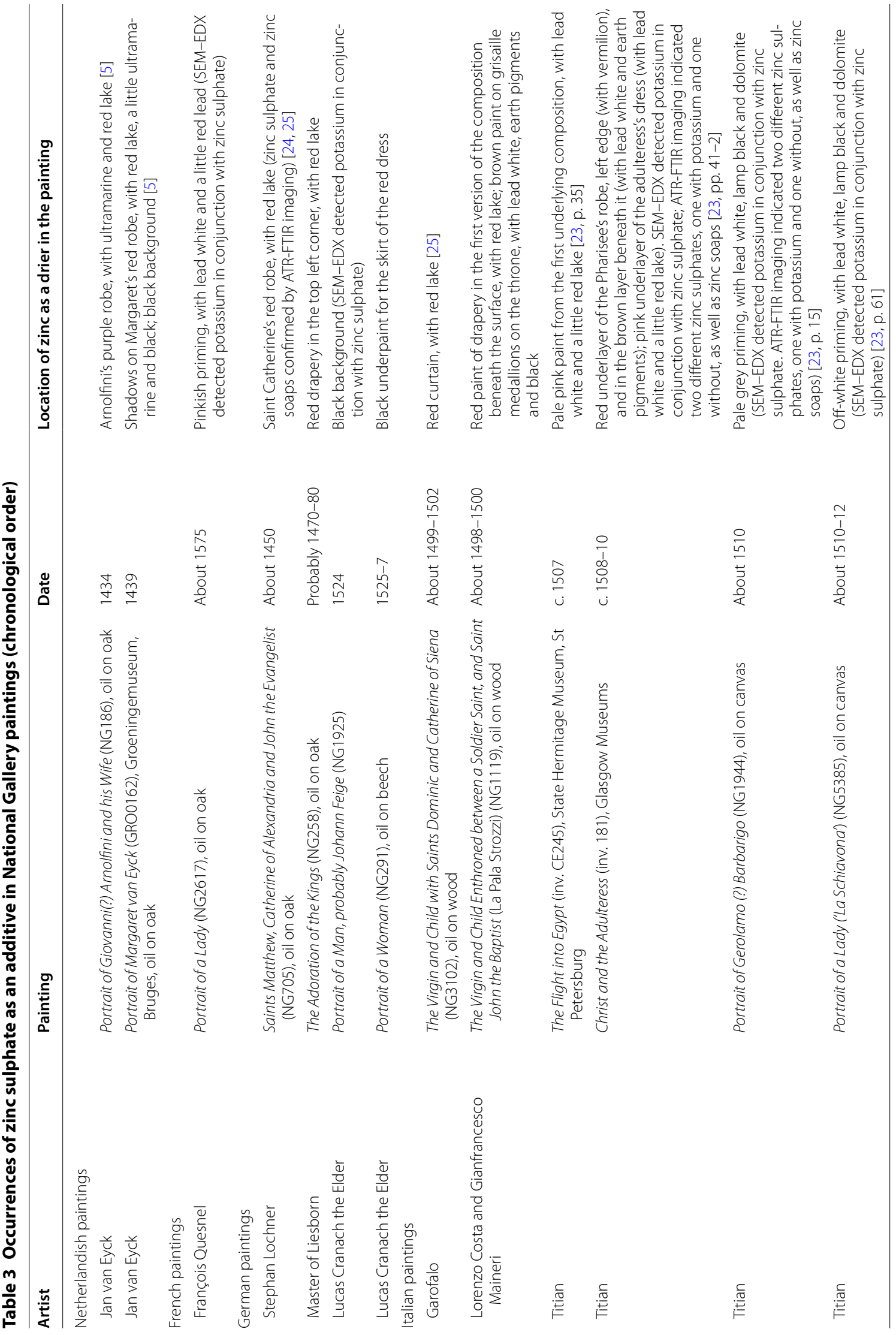




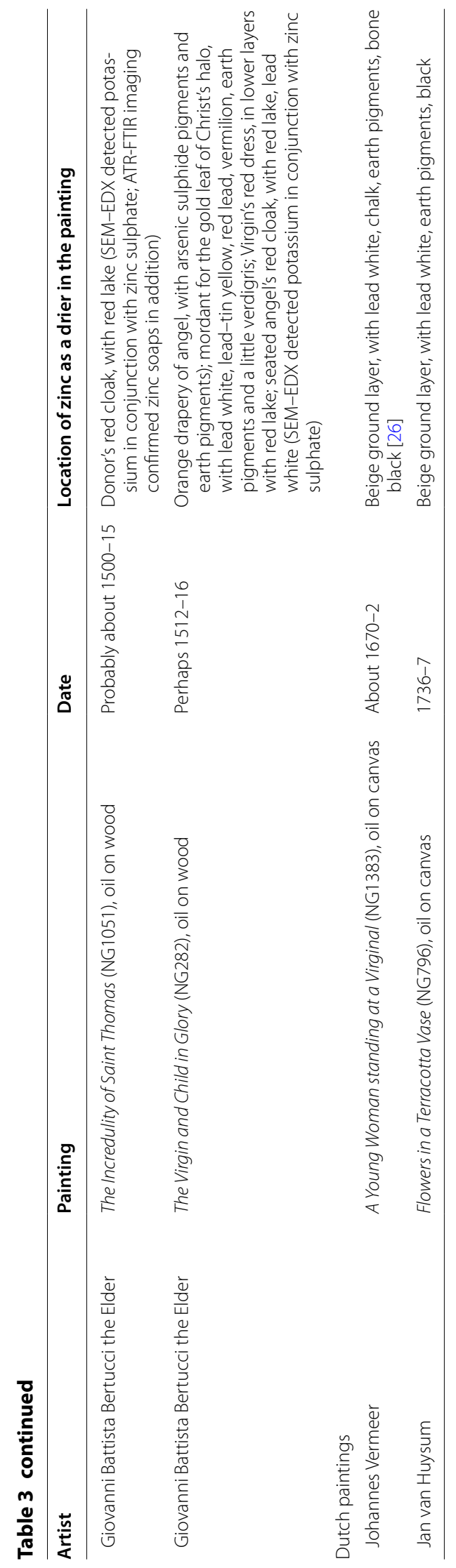


four early paintings by Titian (zinc vitriol has not been found in his later works), four paintings from Ferrara and Bologna of about the same date, a seventeenth-century painting by Vermeer, an eighteenth-century Dutch flower painting by Jan van Huysum, and several works made in Germany. The earliest of these is a mid fifteenth-century panel by Stefan Lochner, who worked in Cologne [24]. A broader study of paintings by this artist carried out by the Doerner Institut, Munich, in collaboration with the Wallraf-Richartz-Museum, Cologne, detected zinc in nearly every painting in areas of red lake and in the blacks, indicating that zinc vitriol was quite commonly used as an additive in Cologne in this period [27]. The geographically dispersed occurrences in Table 3 , ranging in date from the fifteenth to the eighteenth century, are in keeping with the frequent references to zinc vitriol in historical documentary sources over this whole period. By the eighteenth and nineteenth centuries, as noted in a review by Carlyle, it was 'a popular ingredient in drying oil recipes and in combinations of driers such as "Patent dryer"' [28], and it seems likely that it will prove to be more common than the examples identified so far might suggest, even in earlier works. Charles Lock Eastlake, the first Director of the National Gallery, proclaimed it to be the favourite drier of Netherlandish painters, on the basis of his review of Northern European historic treatises in his 1847 book Materials for a History of Oil Painting [29].

The ATR-FTIR imaging on the priming in the crosssection from Titian's Portrait of a Man gave two distinct FTIR spectra. One of these exhibits a complex sulphate infrared absorption band with the maximum centred around $1040 \mathrm{~cm}^{-1}$ together with additional small sharp bands at c. 1157 and $966 \mathrm{~cm}^{-1}$, and correlates with areas found by SEM-EDX to contain only $\mathrm{Zn}, \mathrm{S}$ and $\mathrm{O}$; the other, with a single broad band at c.1060-70 $\mathrm{cm}^{-1}$, corresponds to areas containing some potassium in addition [23]. The spectra from the potassium-containing areas are not an exact match to published data for known potassium zinc sulphates such as $\mathrm{K}_{2} \mathrm{Zn}\left(\mathrm{SO}_{4}\right)_{2} \cdot 6 \mathrm{H}_{2} \mathrm{O}$ [30], and further work is needed to fully identify these species. Nevertheless similar results were obtained from two other paintings by Titian where it was possible to carry out ATR-FTIR imaging, and from the painting by François Quesnel (Table 3 and [23]). The samples from the other paintings in the table were either not suitable for ATR-FTIR imaging, or where this was possible the spectra were not sufficiently distinct. Reassessment of the SEM-EDX results did, however, confirm the presence of potassium in conjunction with the zinc sulphate in every case, at least where no potassium-containing pigments such as red lake or ultramarine were present to interfere with the analyses, including in the portrait by François Quesnel, as illustrated in Fig. 2. The source of white vitriol was the mineral goslarite $\left(\mathrm{ZnSO}_{4} \cdot 7 \mathrm{H}_{2} \mathrm{O}\right)$, and although potassium could be present as an impurity it is also possible that it was introduced through some sort of processing before use. Zinc acts as a secondary or auxiliary drier, but it may be that its effectiveness is dependent on its preparation, since the experiments using pure zinc sulphate in the heptahydrate form published so far have shown rather variable results [31]. Comments in the historical literature also seem to indicate it might not always be reliable for this purpose. Laurie (1895, [32]) states that it is ineffective, but that the sulphate of zinc mentioned in early treatises worked as a drier because it was not pure (although he speculates that this was because manganese was present as an impurity), and Church (1915, [33]) comments that 'Another dryer in common use is white vitriol or sulphate of zinc. Its siccative character is very slight.' Interestingly, given the potassium content in the zinc sulphate found in paintings, Samuel Frederick Gray (1830), under the heading 'boiled oil' states: 'The pure sulphate of zinc made in England has not the same drying quality as the common white vitriol imported from Germany' [34].

\section{Developments in colour and the use of pigments}

Towards the end of the fifteenth century a change in style occurs at the same time as a shift towards less saturated colours and more subtle hues, as can be seen when comparing The Virgin and Child Enthroned by Quentin Massys (Fig. 3) painted about 1506-9 with The Arnolfini Portrait by Jan van Eyck (Fig. 1) dated 1434. This is accompanied by a change in technique that is evident, for example, in the build-up of the modelling in the draperies. Rather than using an opaque red paint for the base layers of red draperies, as Van Eyck would have done, Massys underpainted the whole of the Virgin's cloak in various shades of grey, as can be seen in the cross section (Fig. 3b), before glazing it with red lake to give a soft purplish pink colour. Similarly, the green drapery of the angel at the right of the painting has, beneath a green verdigris glaze, an orange-red base colour that modifies the tone in a subtle way, rather than an opaque green underpaint as would have been typical in fifteenth-century painting (Fig. 3c). This search for more nuanced hues might also be why two more unusual pigments, blue vivianite and purple fluorite, were found in a small number of the sixteenth-century paintings, although it may simply have been a question of availability or perhaps even a need for cheaper pigments to extend the expensive blues and red lakes. The blue hydrated iron phosphate pigment vivianite was used, for example, in another painting by Massys, Christ (NG295.1), mixed with red lake, lead white, a little azurite and black in the underpaint for Christ's red cloak. In the companion panel, The Virgin (NG295.2), the 

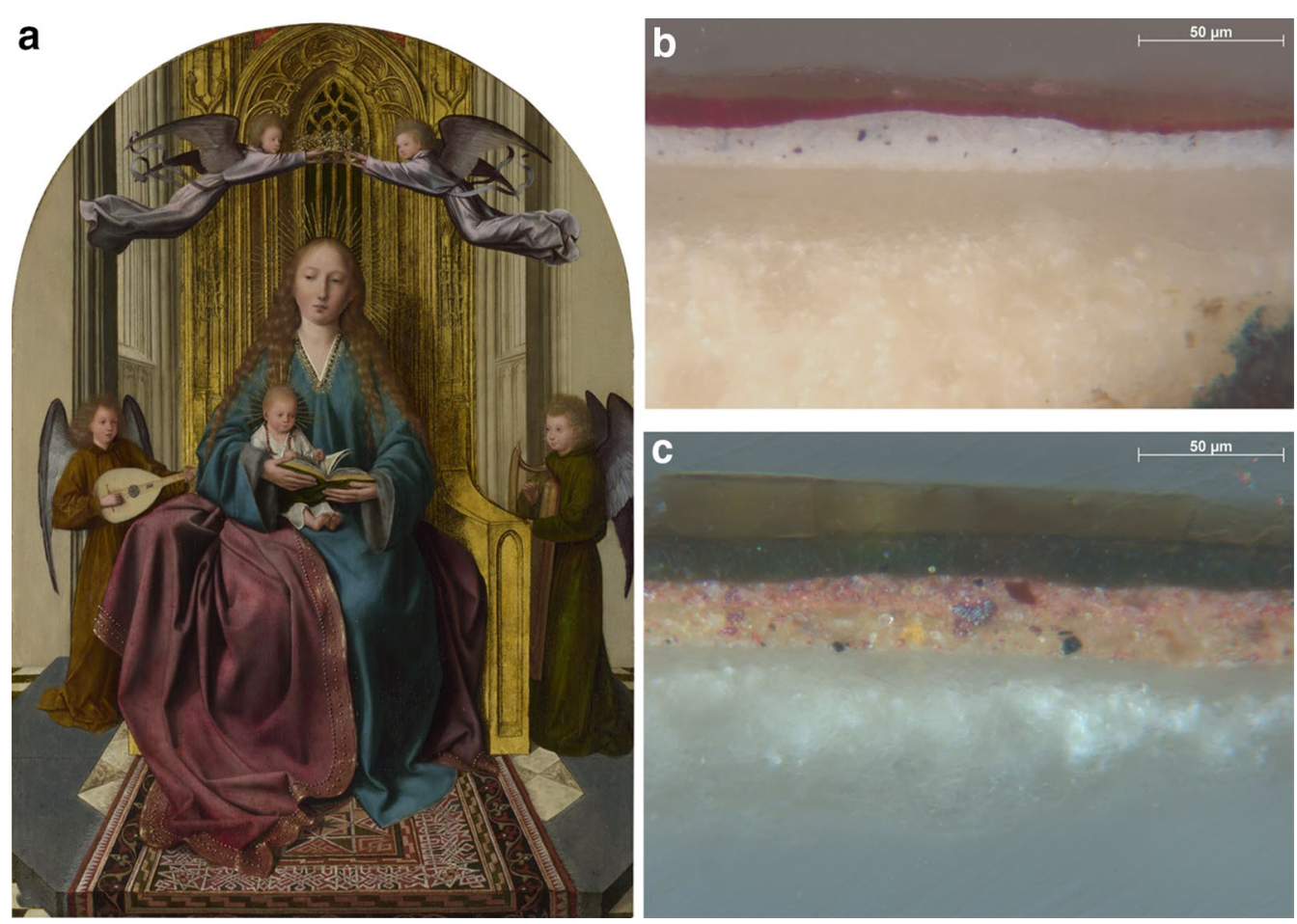

Fig. 3 a Quinten Massys, The Virgin and Child Enthroned, with Four Angels (NG6282), about 1506-9, oil on oak, $62.3 \times 43.5$ cm; b paint cross-section from the Virgin's red cloak, showing the chalk ground (the upper zone of which is more translucent), followed by a thin off white priming, a grey underpaint of lead white and a little black and finally a translucent layer of red lake; c paint cross-section from the green robe of the angel at the right, showing the chalk ground and very thin off white priming, followed by a beige underpaint of lead white, haematite, black and a little red lead, a further undermodelling layer containing a similar mixture but with more haematite, and finally a green layer of verdigris that has reacted with the oil binder to form a homogeneous translucent film. Images @ National Gallery, London

underpaint for the ultramarine blue cloak is a mixture of lead white and purple fluorite (mineral calcium fluoride). Purple fluorite is most common in paintings from southern Germany and the Tyrol [12], where there are wellknown deposits of the mineral. It has also been identified, although far more rarely, in some Netherlandish paintings and while the mineral may have been imported from Germany, it is possible that it came from a more local source such as that in the Fagne/Famenne region of modern-day Belgium [35]. Four occurrences in National Gallery paintings were published in 2000 [7]. Since they are so few in number it is worth reporting here the two further examples in Netherlandish works in the collection discovered since then, and three more in paintings from other collections (analysed by the author and published elsewhere [36, 37]), to bring up to date our understanding of its use in sixteenth-century painting in the Netherlands (Table 4). Purple fluorite has been also reported in a painting entitled 'A Man in Red' thought to have been produced in the Netherlands in the 1530s [38].

In two of the paintings it was mixed with lead white and was the only coloured component of the paint; in the Massys already mentioned, and in a work after Robert
Campin, where it was used for the pale purplish floor tiles [39]. It seems to have been mixed most often with red lake to give a soft purple-pink colour, for example in the angel's robe in The Magdalen in a Landscape (NG2585) by Albert Cornelis [40], and in the sleeves of Gossaert's A Man holding a Glove (NG946) [41]. This portrait was painted in the early 1530 s, and most of the occurrences in the table are from the second or third decade of the sixteenth century. For several of these paintings, however, there are considerable uncertainties in the dating and the attributions, making it difficult to draw firmer conclusions about the distribution in the use of purple fluorite in Netherlandish paintings in terms of date range and geographical location.

\section{The introduction of the blue pigment smalt during the sixteenth century}

The blue pigment smalt, a cobalt-containing potash glass, seems to have been used only rarely before the beginning of the sixteenth century [42]. The occurrences in the paintings in this study bear this out; this pigment was employed in only one of the fifteenth-century works, The Entombment by Dirk Bouts (NG664, probably 1450s), but 
Table 4 Purple fluorite in Netherlandish paintings

\begin{tabular}{|c|c|c|c|}
\hline Artist & Painting title & Date & $\begin{array}{l}\text { Location of purple fluorite in the paint- } \\
\text { ing }\end{array}$ \\
\hline After Robert Campin & $\begin{array}{l}\text { The Virgin and Child in an Apse with Two } \\
\text { Angels (NG2608) }\end{array}$ & About 1500? & $\begin{array}{l}\text { Pale pink tile, with lead white and colour- } \\
\text { less powdered glass }\end{array}$ \\
\hline Workshop of Quinten Massys & The Virgin (NG295.2) & About 1510-25 & $\begin{array}{l}\text { With lead white, in underpaint for the } \\
\text { Virgin's blue drapery (upper layer is } \\
\text { ultramarine) [7] }\end{array}$ \\
\hline Albert Cornelis & The Magdalen in a Landscape (NG2585) & About 1520 & $\begin{array}{l}\text { Pink of angel's robe, mixed with red lake, } \\
\text { lead white and colourless powdered } \\
\text { glass [7] }\end{array}$ \\
\hline Jan Gossaert (Jean Gossart) & Virgin and Child (private collection) & Circa 1520 & $\begin{array}{l}\text { Purple-brown background, in uppermost } \\
\text { layer, mixed with red lake [37] }\end{array}$ \\
\hline Unknown Netherlandish artist & $\begin{array}{l}\text { John Bourchier, 2nd Baron Berners } \\
\text { (National Portrait Gallery, NPG4953) }\end{array}$ & Circa 1520-1530 & Brownish purple sleeve [36, pp. 132-3] \\
\hline Workshop of the Master of the Holy Blood & A Young Man Praying (NG1063) & Probably 1525-30 & $\begin{array}{l}\text { Background; lead white and purple fluorite } \\
\text { (now hidden beneath overpaint) [6, p. } \\
534]\end{array}$ \\
\hline Jan Gossaert (Jean Gossart) & A Man holding a Glove (NG946) & About 1530-32 & $\begin{array}{l}\text { Pink of sleeve, mixed with red lake and lead } \\
\text { white [7] }\end{array}$ \\
\hline Follower of Jan van Scorel & A Man with Pansies and a Skull (NG1036) & About 1535 & $\begin{array}{l}\text { Greyish-purple sleeve, mixed with lead } \\
\text { white, smalt and azurite [7] }\end{array}$ \\
\hline Unknown Netherlandish artist & $\begin{array}{l}\text { Sir Thomas Gresham (National Portrait } \\
\text { Gallery, NPG352) }\end{array}$ & Circa 1565 & $\begin{array}{l}\text { Purplish paint in the slashes in the sitter's } \\
\text { black costume, mixed with white [36, pp. } \\
\text { 132-3] }\end{array}$ \\
\hline
\end{tabular}

was identified in eleven of the paintings in the sixteenthcentury schools catalogue, shown in Table 5 in chronological order. The earliest of these, the Man with Pansies and a Skull by a follower of Jan van Scorel, dates from about 1535. Smalt is present in the collar and sleeves, where it is mixed with fluorite, lead white and azurite. All the other examples date from after 1550, after which smalt becomes extremely common across most of Europe.

Smalt, being a potash glass, is rather unstable; in most cases it has degraded and lost its colour, except where it has sometimes been protected by having been mixed with lead white [42]. The extensive use of this pigment in the four paintings of The Four Elements series by Joachim Beuckelaer has meant that many areas have changed colour dramatically. A range of blues, purples, lilacs and purple-pinks were intended, but the sleeves of the woman in the detail at the right in Fig. 4 which would have been blue are now grey, while those of the woman in the detail at the left, painted with a layer of smalt over a red paint containing mainly red lake and therefore meant to be purplish, are now also mostly grey with a hint of pink where the red underlayer is showing through. The blue colour of smalt derives from tetrahedral coordination of the cobalt in the glass, stabilised by potassium ions, but potassium is leached when it degrades, so that the equilibrium moves towards octahedral coordination with concurrent loss of colour [43,
44]. When the pigment is in good condition it contains around 12-15 weight $\% \mathrm{~K}_{2} \mathrm{O}$ [43-45], but it can be seen in Table 5 that the smalt analysed in two of the Beuckelaers contains only around 2-3\%. In Earth, the third of the series, although there seems to be more potassium present at around 11-12 wt $\%$ oxide, it is not better preserved overall; the results reported are for one particle of smalt that retains its colour because it is large, chosen for analysis because it is more representative of the original composition of the smalt than the deteriorated particles. Smalt was available to artists in different grades that varied in the intensity of colour, so the quantitative analysis, through the potassium content, is useful in distinguishing between a smalt that was always pale and one that is weak in colour due to degradation [45]. The few greyishblue smalt particles in the sample from the sitter's dress in the portrait by François Quesnel, for example (Fig. 2), contain only around $4 \mathrm{wt} \% \mathrm{~K}_{2} \mathrm{O}$ and therefore are not a pale grade but are degraded, as is the rest of the smalt in the sample, which has lost its colour completely. The cobalt content gives an indication of the original strength of colour; at $4.8 \mathrm{wt} \% \mathrm{CoO}$ content, the pigment would originally have been a strong blue.

The intensity of colour in smalt depends on the particle size (finely ground pigment being paler) and on the cobalt content. Different grades were sold distinguished by one or other, or both, of these factors. To be able to recognise a low or high grade based on the cobalt content, it is 


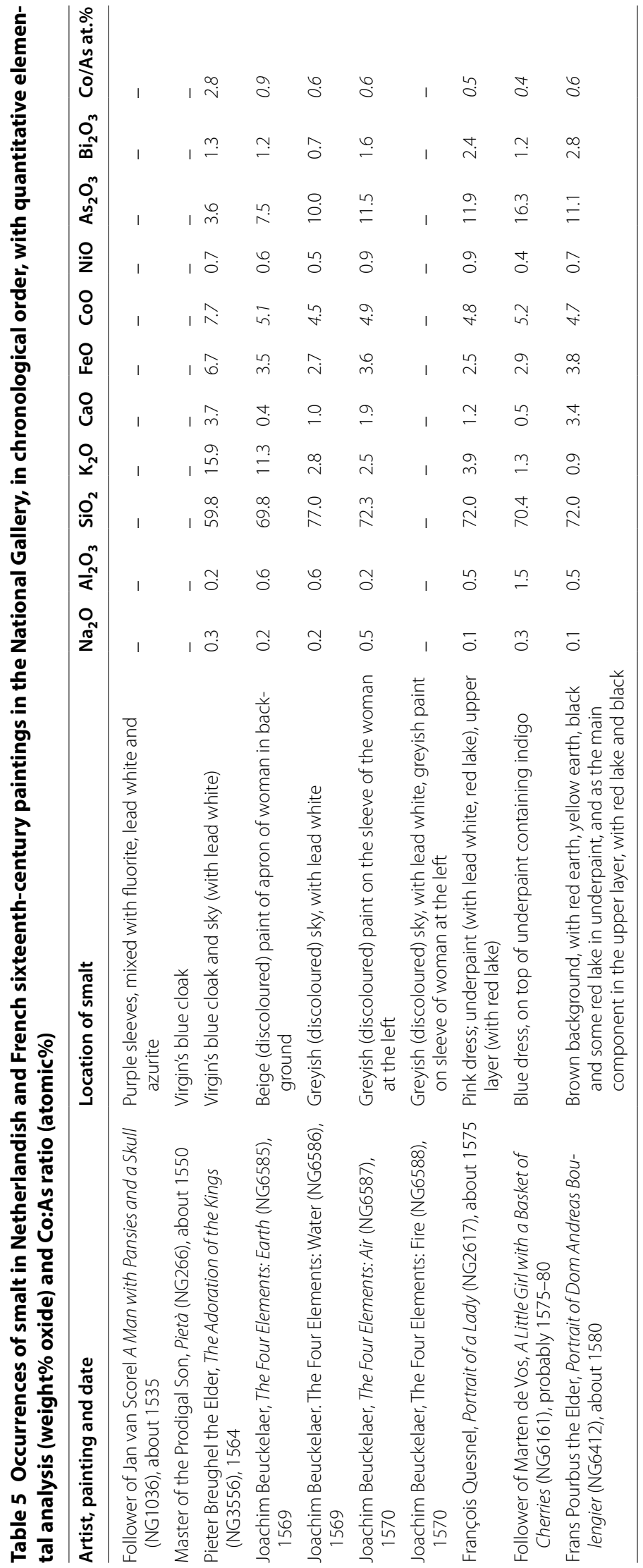



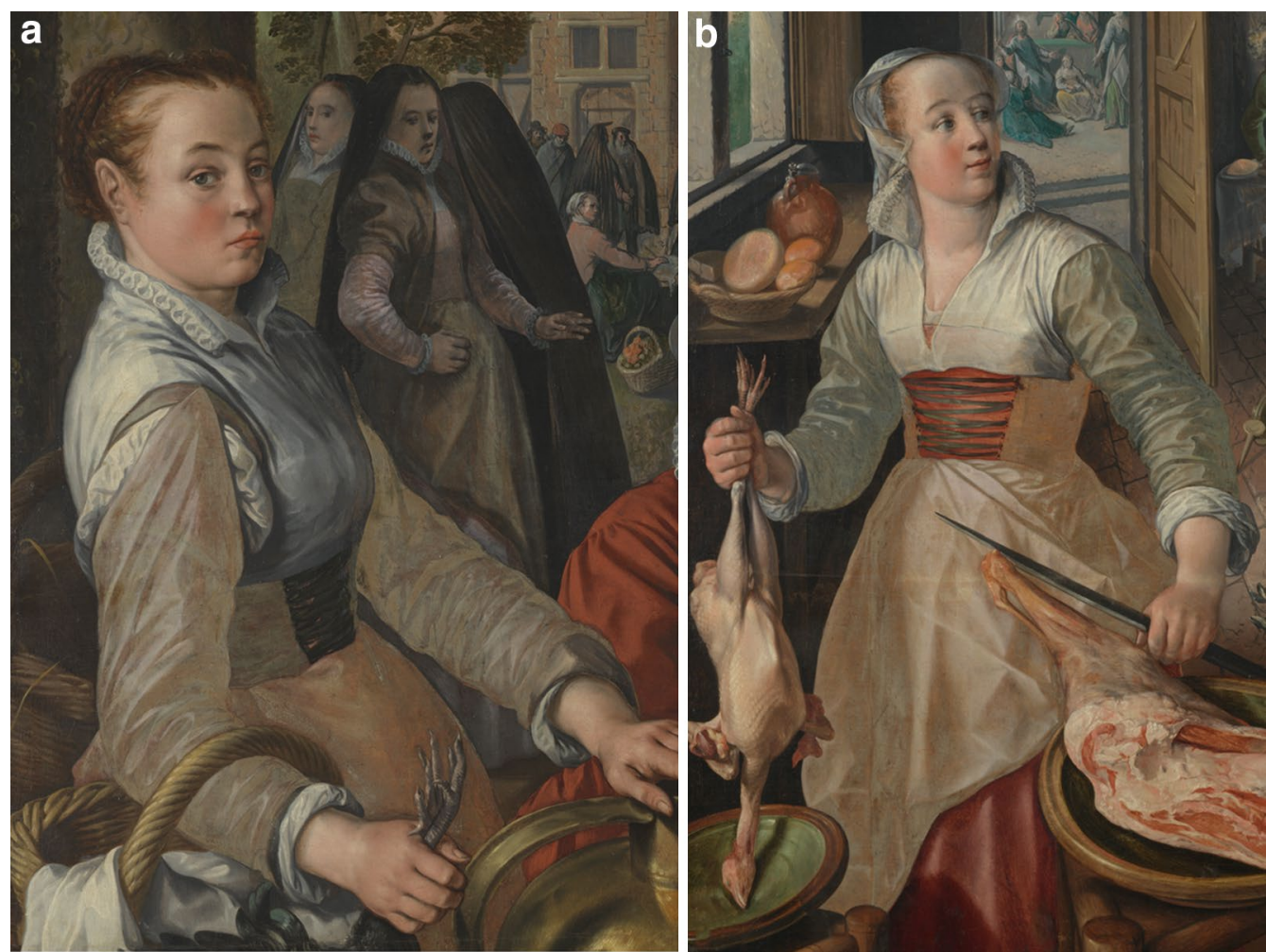

Fig. 4 a Joachim Beuckelaer, The Four Elements: Air (NG6587), 1570, detail showing the woman at the left; b Joachim Beuckelaer, The Four Elements: Fire (NG6588), 1570, detail showing the woman at the left. Images @ National Gallery, London

necessary to consider the broader context of the composition of this pigment. The quantitative analyses included here are part of a broad study of smalt that has included seventy National Gallery paintings so far, ranging in date from the very beginning of the sixteenth century to the first decade of the nineteenth century. An interesting pattern in the cobalt content has emerged. Some of the smalt in the sixteenth-century paintings is very rich in cobalt, such as that in Pieter Brueghel the Elder's Adoration of the Kings, which contains almost $8 \mathrm{wt} \% \mathrm{CoO}$. In all of the paintings in Table 5 dating from before 1600 the cobalt oxide content is above $4-5 \mathrm{wt} \%$. A few of paintings in the broader study dating from after 1600 contain a little above $5 \mathrm{wt} \% \mathrm{CoO}$, but it is more often around 3\%, less than half that measured in the Brueghel [45]. Historic documentary sources seem to indicate that the end of the sixteenth and beginning of the seventeenth century is a period of many changes in the trade in cobalt ore and the smalt making industry. In the sixteenth century smalt made in the Netherlands was famous for its high quality, and smalt was manufactured in a limited number of places, mainly in the Netherlands, due to the strong control over trade in cobalt ore that they had established, and in Saxony, close to the cobalt deposits. At the beginning of the seventeenth century smalt began to be made in more places, and it may be that this led to a reduction of the quality of the smalt, or perhaps manufacturers found they could economise by using less cobalt ore and still achieve a marketable product [45].

The arsenic content in the smalt analyses in Table 5 is considerable, in most cases far exceeding that of cobalt. The most common cobalt ores were arsenates and arsenides, found in the deposits in Saxony that were until the eighteenth century the only source in Europe of cobalt, and typically also containing small amounts of nickel, iron and bismuth. The ore was prepared by first roasting it to remove some of the arsenic. It is clear from the analyses that the degree to which this was done was variable, as evident from the Co/As ratios in Table 5, which allow distinction between variations due to differences in the roasting and those due simply to the amount of cobalt ore that was used. In most cases the amount of cobalt is around half that of arsenic, but the smalt in the Adoration by Breughel is instead rather low in arsenic, with the amount of cobalt being more than twice as much. Clearer trends are likely to become evident as more results become available; it is interesting that a recent study of smalt in paintings by Titian and Veronese in the National 
Gallery showed these to all be rich in arsenic [46]. Arsenic can act as either a network modifier or former in the glass. From the few initial studies by Raman and FTIR microscopy it seems to be behaving as the latter in smalt [44], and in the melt it can also function as a fining agent. Differences in the arsenic content in smalt may therefore be of significance and indicate deliberate choices in the preparation of the ore that manufacturers had discovered would improve the quality of the product, although further research is needed to understand this fully.

\section{Green mineral copper sulphate pigments}

The only green pigment identified in the earlier works among the National Gallery's Netherlandish paintings was verdigris, but in those from the late fifteenth century and onwards into the sixteenth century a surprising number of occurrences were identified of a green copper mineral pigment composed mainly of a copper sulphate; sixteen are listed in Table 6. A few of these had been already discovered before the cataloguing programme, such as that in the green background of the portrait attributed to a follower of Jan van Scorel (NG1036), and in the green areas of The Magdalen in a Landscape by Albert Cornelis (NG2585) [7]. Here, and in most of the other examples, the copper sulphate was accompanied, in addition to a little malachite, by some silica in the form of quartz and some potassium feldspar, so is likely to be a natural mineral rather than an artificially made copper green. In the Cornelis, and in the portrait by a follower of Jan van Scorel, it was possible to carry out Raman microscopy, which confirmed that in these cases the mineral is posnjakite $\left(\mathrm{Cu}_{4} \mathrm{SO}_{4}(\mathrm{OH})_{6} \cdot \mathrm{H}_{2} \mathrm{O}\right)$ [7], although other copper sulphates, most commonly brochantite $\left(\mathrm{Cu}_{4} \mathrm{SO}_{4}(\mathrm{OH})_{6}\right)$, but also langite $\left(\mathrm{Cu}_{4} \mathrm{SO}_{4}(\mathrm{OH})_{6} \cdot 2 \mathrm{H}_{2} \mathrm{O}\right)$ have also been reported in paintings [47]. Posnjakite forms elongated lath-like crystals and tends towards blue-green in colour, while brochantite is a more emerald green, with more rectangular tabular particles. In some of the paint cross-sections, particles of different hues and shapes are evident that might indicate more than one type of copper sulphate is present, for example in Gerard David's Canon Bernardijn Salviati and Three Saints (NG1045) (Fig. 5). The two different FTIR spectra obtained from green particles by ATR-FTIR imaging on a paint cross-section from The Virgin and Child in a Landscape (NG1864) by Albert Cornelis and Associates suggest a mixture of different copper sulphate minerals. That from a lath-like bluish-green particle was similar to a reference standard of antlerite $\left(\mathrm{Cu}_{3} \mathrm{SO}_{4}(\mathrm{OH})_{4}\right)$, while that from a grass-green particle was closer to the reference standard of brochantite $\left(\mathrm{Cu}_{4}\left(\mathrm{SO}_{4}\right)(\mathrm{OH})_{6}\right)$, but in practice it is difficult to confirm these identifications, especially since the spectral sensitivity of the focal plane array detector does not extend below $900 \mathrm{~cm}^{-1}$, and further analyses with micro-XRD and Raman microscopy will be necessary. The elongated blue-green crystals seen in the sample from Marten van Heemskerck's The Virgin and Saint John the Evangelist (NG6508.1) are most typical of the particles seen in the samples listed in Table 6 . In this painting previous analyses had mistakenly identified the pigment as azurite [48], while in other cases such as the painting by Gerard David, it had been thought to be malachite. ATR-FTIR imaging has proved useful in making these distinctions even if it is not always able to determine the precise copper sulphate species (Fig. 6).

The paintings in Table 6 range in date from the beginning of the sixteenth century to around 1540 . A few scattered occurrences in other paintings of this period from the Netherlands as well as in some manuscripts had been reported in the past. The identification of posnjakite (using X-ray diffraction) in paintings by Jan van Scorel was published already in 1977 [49], and here an example is reported in a portrait by a follower of this artist. Other occurrences of this same mineral reliably identified by X-ray diffraction were reported in 1978, in The Last Judgement by Lucas van Leyden (1526-7) [50], and in 1992 in three paintings by Jan Massys [51]. It was identified in two of the National Gallery paintings by Jan's father, Quinten Massys, in the green background in The Ugly Duchess of about 1513, and in the landscape in The Crucifixion of about 1515, considered to be from his workshop. More recently, the HERCULES cultural heritage laboratory at Évora University found that it was used extensively in works by the sixteenth-century artist Frei Carlos, who worked in Portugal but was originally from the Low Countries [47]. The MINIARE project at the Fitzwilliam Museum, Cambridge, on the materials of manuscripts, identified copper sulphates in an early sixteenth-century Book of Hours illuminated by a group of Netherlandish artists [52], as well as in a manuscript illuminated by Simon Bening dating from 1522-3 [53].

Secondary copper minerals such as malachite and copper sulphates are found in the location of copper deposits, formed especially on the tailings of copper mines. They were most probably sold under the names mountain green (berggrün, vert de montaigne, etc.) or verdeazurro (vert d'azur) [54], this last name being especially appropriate for the rather blue-green copper sulphates reported here. Artists would not, of course, have been able to distinguish the copper sulphates from pigments composed mainly of malachite, or of other complex mixtures of green copper minerals such as those that have been found in Italian paintings [55]. Copper mineral pigments composed of mainly malachite are more common in paintings, and the regular use of a mountain green that is predominantly copper sulphate in Netherlandish 


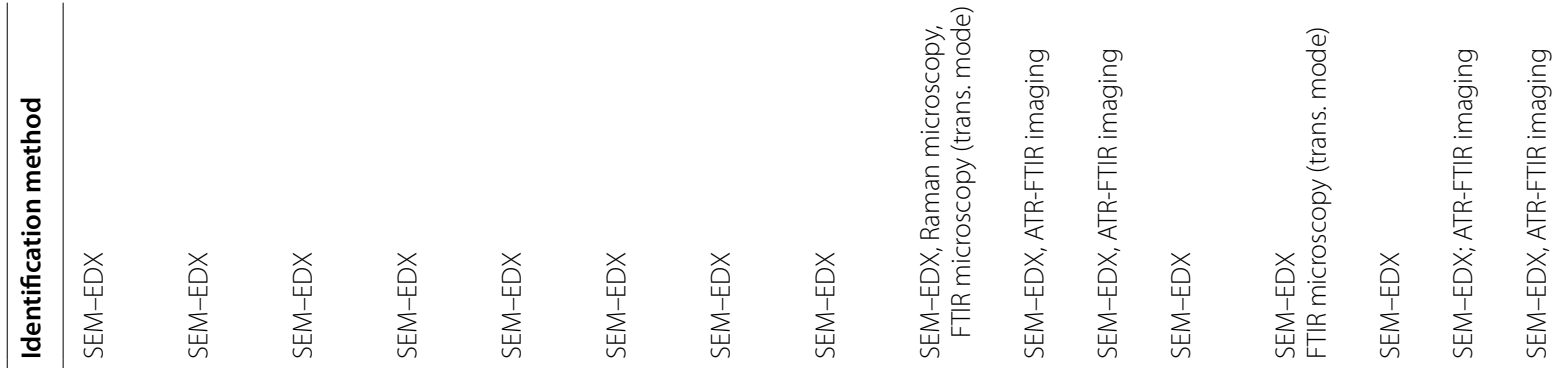

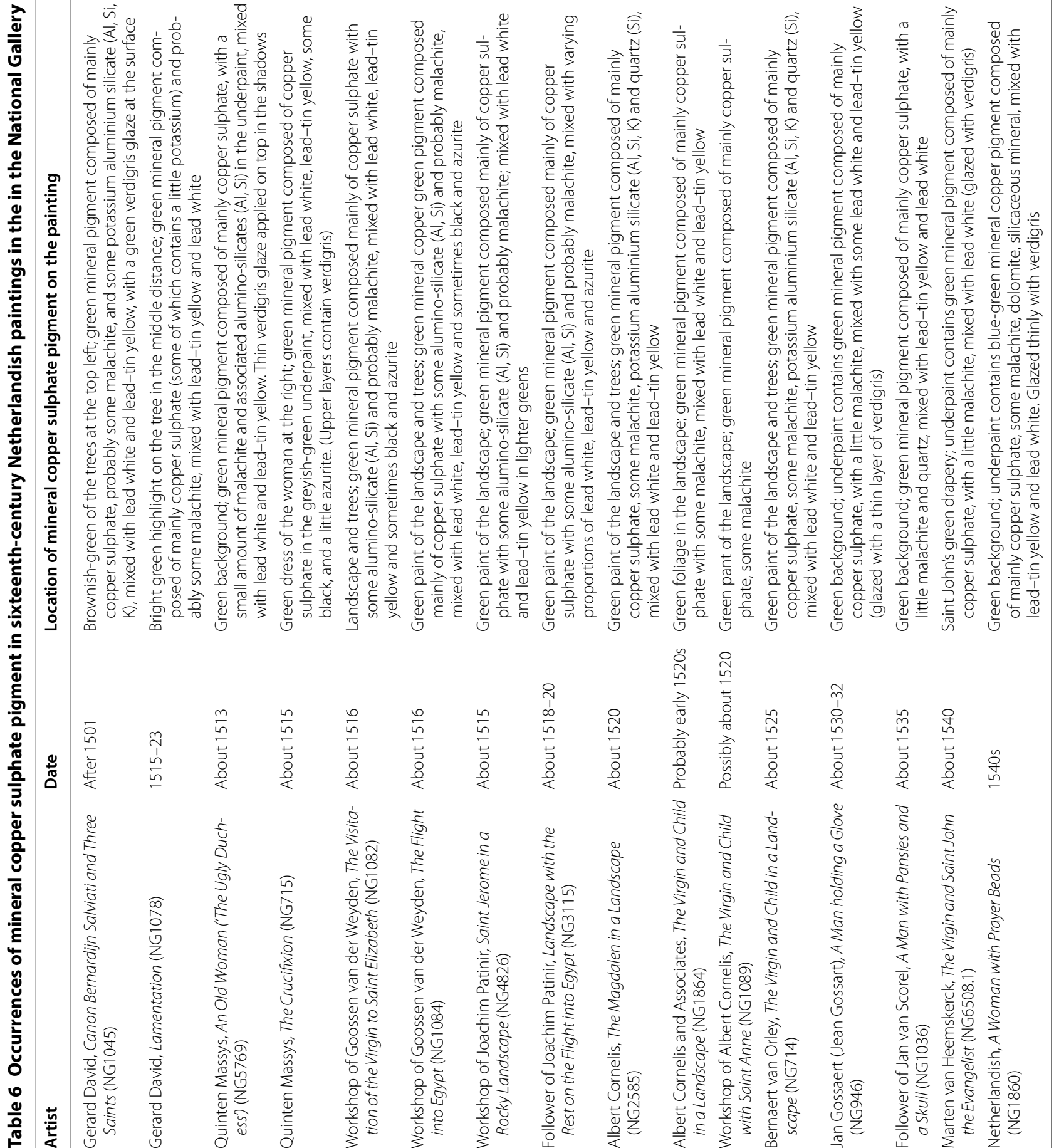




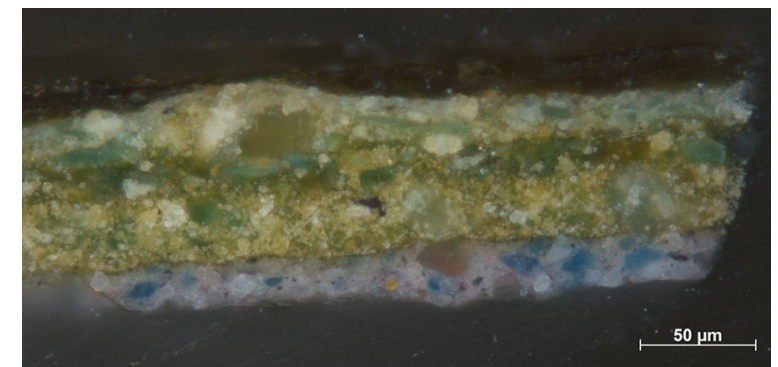

Fig. 5 Gerard David, Canon Bernardijn Salviati and Three Saints (NG1045). Paint cross-section from dark brownish-green leaves on the tree at the top left, showing some blue-green lath-like particles of copper sulphate, and a more tabular green particle towards the right of the sample. Images @ National Gallery, London

paintings of the sixteenth century is likely to indicate a particular deposit as a source. More research on trade links or on the minerals in historic copper mining locations may provide further understanding of why this pigment appears in this location at this time.

This green copper mineral pigment was not used as an alternative to verdigris, since in several of the paintings both pigments are present, the more translucent verdigris being used in glazes on top of more opaque greens containing copper sulphate mineral. In Gerard David's
Canon Bernardijn Salviati and Three Saints (NG1045) (Fig. 5) a mixture of copper sulphate mineral with lead white and lead-tin yellow is used for the lighter more opaque greens in the landscape, while the darkest greens in the leaves are applied on top in verdigris. In Marten van Heemskerck's The Virgin and Saint John the Evangelist (NG6508.1) (Fig. 6), mineral copper sulphate is present mixed with varying proportions of lead white for the undermodelling of Saint John's drapery, which has then been glazed with a deep green layer of verdigris.

\section{Conclusions}

Bringing together the results from the technical examinations of the materials in fifteenth- and sixteenth-century Netherlandish and French paintings during the National Gallery cataloguing programmes, and re-evaluating them in the context of earlier research has provided new insights, strengthening the earlier hypotheses made on the basis of fewer analyses. The colourless powdered glass found often as a paint additive in paintings of this period shows interesting trends in composition, with glass of a high lime-low alkali composition predominating in the later paintings, an observation that could be useful in helping to date paintings in the future. Zinc sulphate, although less common than glass as an additive, was nevertheless more widespread than has been recognised, and
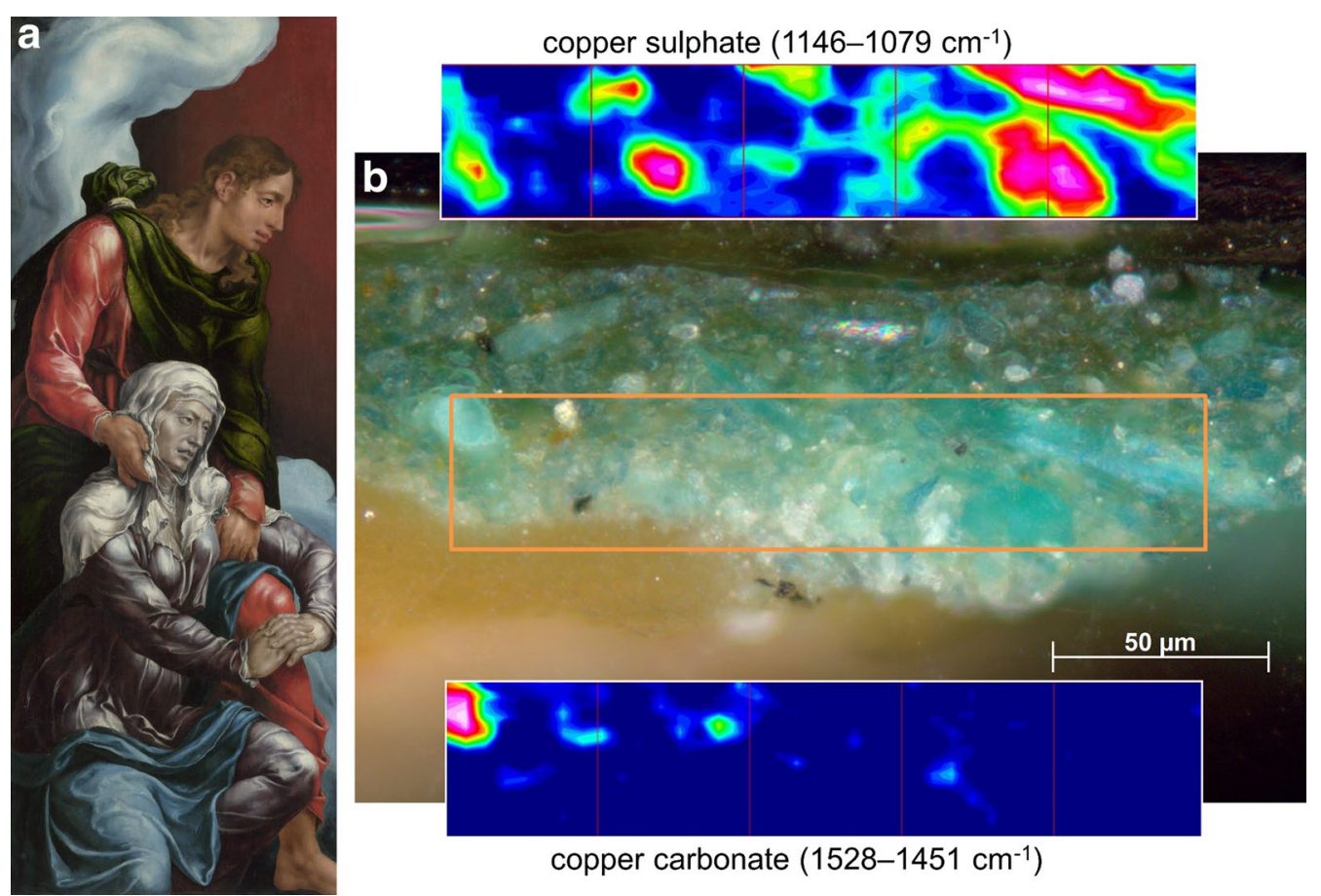

Fig. 6 a Marten van Heemskerck, The Virgin and Saint John the Evangelist (NG6508.1); b paint cross-section from Saint John's green robe, showing the underpaint containing long lath-like blue-green particles of copper sulphate, on top of which is a thin verdigris glaze. The ATR-FTIR image showing the distribution of the infrared absorption band in the range $1146-1079 \mathrm{~cm}^{-1}$ shows the location of copper sulphates, while that at 1528-1451 $\mathrm{cm}^{-1}$ shows copper carbonate (malachite) in the few more rounded particles. Images @ National Gallery, London 
it is important to be aware that it can be present in these early paintings when carrying out non-invasive analyses, since the detection of zinc might be mistakenly interpreted as indicating the presence of zinc white in later non-original paint.

The rare pigments vivianite and fluorite were identified in a few sixteenth-century works, and along with the more complex mixtures and layer structures compared to earlier works, they contribute to the more nuanced range of colours that distinguishes the later paintings. The most important developments over the period addressed in this article, however, were the introduction of the blue pigment smalt in the sixteenth century, its instability having consequences for the current appearance of paintings from this period, and the green mineral pigment composed of copper sulphate. In earlier works, greens are generally verdigris mixed with yellow pigments, or a blue/yellow mixture such as azurite and lead-tin yellow. These new studies coupled with the scattered occurrences that had already been reported elsewhere make it clear that it was rather common.

\section{Methods}

\section{Optical microscopy}

Optical microscopy was carried out using a Leica DM4000M microscope and a Zeiss AxioCam HRc camera for recording images. A filter system A (BP 340-380 nm, dichromatic mirror: $300 \mathrm{~nm}$, suppression filter: LP $425 \mathrm{~nm}$ ) was used for UV excitation.

\section{Scanning electron microscopy, coupled}

\section{with energy-dispersive X-ray analysis (SEM-EDX)}

SEM-EDX analysis was carried out using a Carl Zeiss $\mathrm{EVO}^{\circledR}$ MA10 variable pressure scanning electron microscope (SEM) coupled to an Oxford Instruments X-Max $80 \mathrm{~mm}^{2}$ energy dispersive X-ray spectrometer, using INCA 350 software. The operating parameters were $20 \mathrm{kV}, 200 \mathrm{pA}$ beam current, approx. $30 \mathrm{~Pa}$ chamber pressure (the minimum necessary to limit charging) with air or water as the chamber gas.

For the methodology for quantitative analysis of the colourless glass and smalt under variable pressure conditions, and the accuracy limits see Refs. [8, 45]. Spot measurements were made on several particles in each sample, from which it was possible to assess the consistency of the composition, and to determine whether more than one type of glass was present, or whether there were variations due to differing degrees of leaching. Where all the particles were reasonably homogeneous, the values quoted in the table are an average of the results. In the samples where some of the glass was leached, the composition of the least altered particle is listed, as this will be closest to its original state. For some paintings, the results from different particles could be sorted into distinct compositional groups, each of which is included in the table.

\section{ATR-FTIR microspectroscopic imaging}

Spectra were acquired from embedded paint cross-sections using a Bruker Tensor 27 FTIR Spectrometer connected to a Hyperion 3000 Series microscope, fitted with a $64 \times 64$ (4096 pixels) FPA detector (range $=4500$ $900 \mathrm{~cm}^{-1}$ ), cooled with liquid nitrogen. The microscope was fitted with a CCD camera, $\mathrm{X}-\mathrm{Y}$ stage (adjustment accuracy of $0.1 \mu \mathrm{m}$ ) and a dedicated ATR objective (20× magnification). The ATR had a germanium crystal with a tip size of $250 \mu \mathrm{m}$. Both spectrometer and microscope were purged with water- and $\mathrm{CO}_{2}$-free air. 128 scans were collected at a resolution of $4 \mathrm{~cm}^{-1}$. The $64 \times 64$ pixel focal plane array collects image data from a $32 \times 32 \mu \mathrm{m}$ square. An effective (diffraction limited) lateral spatial resolution of 3-5 $\mu \mathrm{m}$ is achieved.

\section{Acknowledgements \\ The author is grateful to colleagues in the National Gallery Scientific Depart- ment, David Peggie, and Rachel Morrison, who carried out the ATR-FTIR imaging analyses, as well as to Janet Ambers, British Museum, who conducted the Raman Microscopy.}

\section{Competing interests}

The author declares that she has no competing interests.

\section{Availability of data and materials}

Most of the data on which the conclusions of the manuscript rely is published in this paper, and the full data is available for consultation on request in the files of the Scientific Department, National Gallery, London.

\section{Consent for publication}

Not applicable.

Ethics approval and consent to participate

Not applicable.

Funding

Not applicable.

\section{Publisher's Note}

Springer Nature remains neutral with regard to jurisdictional claims in published maps and institutional affiliations.

Received: 10 March 2017 Accepted: 18 August 2017

Published online: 19 September 2017

\section{References}

1. Coremans P, Thissen J. Materiaux origineaux et technique picturale eyckienne. In: Les primitifs Flamands III. Contributions a l'etude des primitives flamands. 2. L'Agneau mystique au laboratoire, Examen et traitement sous la direction de Paul Coremans. Antwerp: De Sikkel; 1953. p 69-6.

2. Campbell L, Foister S, Roy A, editors. Early Northern European Painting. Natl Gall Tech Bull. 1997

3. Campbell L. National Gallery Catalogues. The Fifteenth Century Netherlandish Schools. London: National Gallery; 1998. 
4. Spring M. The materials of Rogier van der Weyden and his contemporaries in context. In: Campbell L, van der Stock J, Reynolds C, Watteeuw L, editors. Rogier van der Weyden in Context. Leuven: Peeters; 2012. p. 93-105.

5. Spring M, Morrison R. Van Eyck's technique and materials: historical perspectives and contemporary context. In: Currie C, Fransen B, Henderiks V, Stroo C, Vanwijnsberghe D, editors. Van Eyck Studies. Papers presented at the Eighteenth Symposium for the Study of Underdrawing and Technology in Painting, Brussels, 19-21 September 2012. Leuven: Peeters; 2016. p 189-213.

6. National Campbell L, Catalogues Gallery. National Gallery Catalogues. The Sixteenth Century Netherlandish and French Schools. London: National Gallery; 2014.

7. Spring M. Occurrences of the purple pigment fluorite on paintings in the National Gallery. Natl Gall Tech Bull. 2000;21:20-7.

8. Spring M. Colourless powdered glass as an additive in fifteenth- and sixteenth-century European paintings. Natl Gall Tech Bull. 2012;33:4-26.

9. Spring M. Perugino's painting materials: analysis and context within sixteenth-century easel painting. In: Postprints of the workshop on the painting technique of Pietro Vannucci, called il Perugino, organised by INSTM and LabS-TECH, Perugia April 14th-15th 2003, Quaderni di Kermes. Florence: Nardini; 2004: p. 17-24.

10. Roy A, Spring M, Plazzotta C. Raphael's early work in the National Gallery: paintings before Rome. Natl Gall Tech Bull. 2004;25:4-35.

11. Spring M. Raphael's materials: some new discoveries and their context within early sixteenth-century painting. In: Roy A, Spring M, editors. Raphael's painting technique: working practices before Rome, Proceedings of the Eu-ARTECH workshop, National Gallery, London, November 11th 2004, Quaderni di Kermes. Florence: Nardini; 2007: p. 77-86.

12. Spring M. Pigments in sixteenth-century painting of the German School. In: Béguerie-De Paepe P, Menu M, editors. The pictorial technique of Grünewald and his peers. Colmar: Musée d'Unterlinden and C2RMFCNRS; 2007. p. 136-44.

13. Kirby Talley M. Portrait painting in England: studies in the technical literature before 1700. London: Paul Mellon Centre; 1981.

14. Lutzenberger K, Stege H, Tilenschi C. A note on glass and silica in oil paintings from the 15 th to the 17 th century. J Cult Herit. 2010;11:365-72.

15. Dietz S, Krekel C, Obermeier A, Stege H. Ground glass in Holbein the Elder's work. In: Wallert A, editor. Painting techniques: history, materials and studio practice, 5th International Symposium, Rijksmuseum, Amsterdam, 18-20 September 2013. Amsterdam: Rijksmuseum; 2016. p. 43-7.

16. Provisional translations provided by the making and knowing project. New York: Columbia University. http://www.makingandknowing.org.

17. Stern WB, Gerber Y. Potassium-calcium glass: new data and experiments. Archaeometry. 2004:46:137-56.

18. Janssens K, Deraedt I, Adams F, Veeckman J. Composition of 15-17th century archaeological glass vessels excavated in Antwerp. Belgium. Microchimica Acta. 1998;Suppl.15:253-67.

19. Caen J, Schalm O, Janssens K. 15th century stained glass windows in the former county of Flanders; a historical and chemical study related to recent conservation campaigns. In: Janssens K, Degryse P, Cosyns P, Caen J, Van't dack L, editors. Annales du 17e Congrés de l'Association Internationale pour Histoire du Verre. Antwerp: Einband; 2006: p. 459-66.

20. Baker C, Henry T. The National Gallery complete illustrated catalogue. London: National Gallery; 1995. p. 69.

21. Bartl A, Krekel C, Lautenschlager M, Oltrogge D. Der "Liber illuministarum" aus Kloster Tegernsee. Stuttgart: Franz Steiner Verlag; 2005. p. 90-1.

22. Moioli P, Seccaroni C. Characterisation of iron based pigments through XRF analysis. In: Van Grieken R, Janssens K, Van't dack L, Meersman G, editors. Art 2002, 7th International Conference on Non-destructive Testing and Microanalysis for the Diagnostics and Conservation of the Cultural and Environmental Heritage, Proceedings. Antwerp: University of Antwerp; 2002.

23. Dunkerton J, Spring M, with contributions from Billinge R, Kalinina K, Morrison R, Macaro G, Peggie D, Roy A. Titian's painting technique before 1540. Natl Gall Tech Bull. 2013:34.

24. Spring M, Billinge R, Peggie D, Morrison R. The technique and materials of two paintings from fifteenth-century Cologne in the National Gallery, London. Zeitschrift für Kunsttechnologie und Konservierung, Die Sprache des Materials. 2012;26(1):88-99.
25. Kirby J, Spring M, Higgitt C. Insight into the technology of red lake pigment manufacture through study of the dyestuff substrate. Natl Gall Tech Bull. 2005;26:71-87.

26. http://www.nationalgallery.org.uk/paintings/research/meaning-of-making/vermeer-and-technique/formation-of-lead-and-zinc-soaps. Accessed 21 June 2017.

27. Stege H, Tilenschi C, Sanyova J. Neues zu den Pigmenten der Altkölner Malerei. Zeitschrift für Kunsttechnologie und Konservierung, Die Sprache des Materials. 2012;26(1):71-9.

28. Carlyle L. Paint driers discussed in nineteenth-century British oil painting manuals. J Am Inst Conserv. 1999;38(1):69-82.

29. Eastlake CL. Methods and materials of painting of the great schools and masters, first published 1847 under the title Materials for a History of Oil Painting, republished. London: Dover; 1960.

30. Singh $B$, Gupta SP, Khanna BN. The infrared and laser Raman spectra of $\mathrm{K}_{2} \mathrm{Zn}\left(\mathrm{SO}_{4}\right)_{2} \cdot 6 \mathrm{H}_{2} \mathrm{O}$. Pramana J Phys. 1982;18:427-37.

31. Kneepens I. Understanding historical recipes for the modification of linseed oil, unpublished Master of Arts thesis. Amsterdam: Department of Art History, University of Amsterdam; 2012.

32. Laurie AP. Facts about processes, pigments and vehicles: a manual for art students. London: MacMillan; 1895. p. 86.

33. Church AH. The chemistry of paints and painting. London: Beeley, Service \& Co Ltd; 1915.

34. Gray SF. The chemistry of the arts: being a practical display of the arts and manufactures which depend on chemical principles, vol. 1. Philadelphia: Carey \& Lea; 1830. p. 618.

35. Neutkens H, Orinx M. Neu und schön: calcit und Fluorit aus Belgien. Lapis. 2007;32(2):13-8.

36. Sheldon L. Palette, practice and purpose: pigments and their employment by native and Anglo-Netherlandish artists in Tudor and Jacobean paintings. In: Cooper T, Burnstock A, Howard M, Town E, editors. Painting in Britain 1500-1630. Oxford: Oxford University Press; 2015. p. 128-37.

37. Alsteens S, Orenstein N, Campbell L. Man, myth, and sensual pleasures: Jan Gossart's Renaissance: the complete works by Jan Gossaert. New York and London: Metropolitan Museum of Art and National Gallery. p. 164-6.

38. Kempski M. A note on the use of the purple pigment fluorite on The Man in Red. In: Wrapson L, editor. Hamilton Kerr Institute Bulletin number 6. London: Archetype; 2016. p. 62-6.

39. http://www.nationalgallery.org.uk/paintings/after-robert-campin-thevirgin-and-child-in-an-apse-with-two-angels. Accessed 20 June 2017.

40. http://www.nationalgallery.org.uk/paintings/albert-cornelis-the-magdalen-in-a-landscape. Accessed 20 June 2017.

41. http://www.nationalgallery.org.uk/paintings/jan-gossaert-jean-gossart-aman-holding-a-glove. Accessed 20 June 2017.

42. Spring M, Higgitt C, Saunders D. Investigation of pigment-medium interaction processes in oil paint containing degraded smalt. Natl Gall Tech Bull. 2005;26:56-70.

43. Robinet L, Spring M, Pages-Camagna S, Vantelon D, Trcera N. Investigation of the discoloration of smalt pigment in historic paintings by micro X-ray absorption spectroscopy at the Co K-edge. Anal Chem. 2011:83(13):5145-52.

44. Robinet L, Spring M, Pagès-Camagna S. Vibrational spectroscopy correlated with elemental analysis for the investigation of smalt pigment and its alteration in paintings. Anal Methods. 2013;5:4628-38.

45. Spring M, Kugler V, Bean S. Quantitative energy dispersive X-ray analysis of the blue pigment smalt in the variable pressure scanning electron microscope. In: Meeks N, Cartwright C, Meek A, Mongiatti A, editors. Historical technology, materials and conservation, SEM \& microanalysis. London: Archetype; 2012. p. 114-22.

46. Dunkerton J, Spring M, Billinge R, Howard H, Macaro G, Morrison R, Peggie D, Roy A, Stevenson L, von Aderkas N. Titian after 1540 technique and style in his later works. Natl Gall Tech Bull. 2015;36:6-39.

47. Valadas S, Freire RV, Cardoso A, Mirão J, Dias CB, Vandenabeele P, Candeias A. On the use of the unusual green pigment brochantite $\left(\mathrm{Cu}_{4}\left(\mathrm{SO}_{4}\right)(\mathrm{OH})_{6}\right)$ in the 16th-Century Portuguese-Flemish paintings attributed to the Master Frei Carlos Workshop. Microsc Microanal. 2015;21 (2):518-25.

48. Dunkerton J, Burnstock A, Smith A. Two Wings of an Altarpiece by Martin van Heemskerck. Natl Gall Tech Bull. 1988;12:16-35.

49. Asperen Van, de Boer JRJ. Examen scientifique des peintures du groupe Van Scorel, in Jan van Scorel d'Utrecht. Douai: Musée de la Chartreuse; 1977. 
50. Hermesdorf M, Wurfbain ML, Groen K, van Asperen de Boer JRJ, Filedt Kok JP, Wardle P. The examination and restoration of "The last judgement" by Lucas van Leyden. Nederlands Kunsthistorisch Jaarboek (NKJ)/Netherlands Yearbook for History of Art. 1978;29:311-424.

51. Martin E, Eveno M. Contribution to the study of old green copper pigments in easel paintings. In: Marabelli M, Santopadre P, editors. 3rd International Conference on non-destructive testing, microanalytical methods and environment evaluation for study and conservation of works of art. Brescia: Italian Society for Non-destructive Testing; 1992: p. 779-92.

52. Ricciardi P, Panayatova S. New discoveries on the Fitzwilliam Book of Hours. In: Manuscripts in the making: art and science, 8-10 December 2016, Book of Abstracts; 2016.
53. Bertoletti G, Ricciardi P. Simon Bening's palette and painting techniques in the Hours of Albert Brandenburg. In: Manuscripts in the making: art and science, 8-10 December 2016, Book of Abstracts; 2016.

54. Krekel C, Haller U, Burmester A. Artists' pigments reconsidered: does modern science match the historical context? In: Saunders D, Townsend $J \mathrm{H}$, Woodcock S, editors. The object in context: crossing conservation boundaries: contributions to the Munich Congress 28 August-1 September 2006. London: International Institute for Conservation; 2006. p. 244-8.

55. Heydenreich G, Spring M, Stillhammerova M, Pina CM. Malachite pigment of spherical particle form. In: Verger I, editor. ICOM Committee for Conservation, 14th Triennial Meeting, The Hague, Preprints Vol. I. London: James \& James; 2005. p. 480-9.

\section{Submit your manuscript to a SpringerOpen ${ }^{\odot}$ journal and benefit from:}

- Convenient online submission

- Rigorous peer review

- Open access: articles freely available online

- High visibility within the field

- Retaining the copyright to your article

Submit your next manuscript at $\boldsymbol{\nabla}$ springeropen.com 